\title{
The Implementation of Performance-Based Budgeting Through A Money Follow Program in Impressing Budget Corruption
}

\author{
Dadang Suwanda ${ }^{1 *}$, Reydonnyzar Moenek ${ }^{2}$, Sampara Lukman $^{3}$, Muhammad Syaifullah $^{4}$ \\ 1,2,3 Institute Government of Home Affairs (IPDN) \\ ${ }^{4}$ IAIN Pontianak, West Kalimantan \\ *Correspondence email: dadang_suwanda@ipdn.ac.id, reydonnyzar_moenek@ipdn.ac.id, \\ sampara_lukman@ipdn.ac.id, zeliq_ipul@yahoo.com
}

\begin{abstract}
Performance-based budgeting is an integrated annual performance planning which shows the relationship between the funding level and the program desired outcome while money follow program concept is a budgeting approach focusing on programs/activities related to local priorities which have a direct impact on the society. This study aims to evaluate the implementation of performance-based budgeting with money follow program concept in local government planning and budgeting. This study used a qualitative descriptive analysis approach from budget data taken off during 2017-2019. The indicators used in evaluating performance-based budgeting were the establishment of organizational strategies, activities determination and performance evaluation of previous periods. The results showed that the local government had implemented a performance-based budgeting with money follow program concept in their planning and budgeting activities. This could be seen from their establishment of organizational strategies (visions, missions, goals and objectives), activities determinations, and previous period performance evaluations.
\end{abstract}

Keywords: Planning; Budgeting; Performance; Performance-Based Budgeting; Money Follow Program

\section{INTRODUCTION}

The implementation of performance-based budgeting in government administration has been at the center of public management reform in the last decade (Ateh, Prasojo, \& Huseini, 2019; Mazur, 2020; Miller, 2018; Yuhertiana \& Fatun, 2020a). However, current researchers are skeptical of it (de Vries \& Nemec, 2019). In recent years, the interest level in enactment of performance-based rises in more detail along with the increasing support from almost all countries adopting performance-based government administration (Robinson \& Last, 2009) including performance-based budgeting implementation in various government level (Hijal-Moghrabi, 2019; Kim \& Park, 2008; Robinson, 2013; Yenice, 2020). Efforts have been made to include performance measures in reporting, managing, budgeting and strategic planning (Kural \& Akdemir, 2020; Wang, 2000; Yuhertiana \& Fatun, 2020b). The enactment of performance-based in budgeting process is shown from the activities implementation output (Miller, 2018) and it runs parallel with rules and procedures control (Andrews, 2006).

Financial management field reformation in global governance changes continuously following almost all countries budgetary policies especially in the budgeting system which have brought basic changes (Laurenceson \& Chai, 2003; Zhang, Tantardini, Kim, \& de Lancer Julnes, 2020). One of them is the enactment of performance-based budgeting approach stated in planning and budgeting documents which are government work plans and budgets (Andrews \& Hill, 2003a). Efforts have been implemented and developed including budgeting system changes and developments as study and evaluation results of budgeting system implementation (Andrews \& Hill, 2003b; Siti-Nabiha \& Jurnali, 2020). However, the efforts made are not as expected. Besides, developments in government financial management field also require budgeting system growth conformable with existing conditions (Ellul \& Hodges, 2019) and it is continuously fixed for better budget preparation and quality.

The fundamental difference has been found between the old approach and the new approach in budgeting system which the old approach pays more attention to provide the input resources required by each government organization while the new approach is more achievement results oriented in resources allocation determination. This planning and budgeting process is the important process due to the direction of the organization movement. Therefore this process is constantly improved for achieving better credible budget. One of the improvement effort done in improving the credible budget is by introducing the money follow program principle. This principle was introduced in Indonesia at the the kick off Government Work Plan preparation in 2017 as a substitute of the money follow function principle based on the the lack of government budget allocations focus analysis especially in supporting the government priority programs. The President directed the budget allocation in government top priority agenda activities. To ensure the democratic, transparent, accountable, efficient, and effective governance enforcement, it is necessary to have thoughts designed according to the strategic plans, visions, missions, goals, objectives, programs, and activities. 
Budget is the management tool to achieve organizational goals. It is essential tool for linking the planning process and the control process. As a control tool, it provides a detailed plan for government revenue and expenditure so the expenditure made can be accounted for public.

Budgeting in the government sector is a complex and long process which cannot be separated from politicization. This complexity is due to the absence of the agreement accepted by all parties regarding how to allocate government funding sources in an orderly manner. This disagreement is partly caused by political problems, the existence of different leadership values in decision making, and the existence of debates about how the budgeting system can satisfy all parties concerned, therefore current allocations are based on performance targets. In the planning and budgeting process, the government tends to allocate the budget allocation evenly ( peanut butter costing ) rather than based on the priorities so the organization tends to receive minimum budget. Budget allocation is usually based on the tasks and the functions rather than the national development achievement goal priorities in providing the best benefits for society.

In budgeting, agencies or work units are encouraged to have outcome and output oriented. The budget is allocated mostly to government priority or main agenda activities. Beside, budget allocation amount determination must fit the efficiency principle. The budget given to each apparatus function must be adjusted to the mutual determined program priorities.

By implementing money follow program, the government ensures that the establishment priorities movement can run well. This concept is a budgeting approach focusing on programs/activities related to national priorities which have direct impact on society. Less focused in planning and budgeting will hamper the national development and loss in some government goals and targets. Time efficiency is one of the positive results from the implementation of money follow program since it precedes priority objectivity to make clear and measurable achievement goal development. Likewise, the relevant stakeholders are in one agreement in term of programs and activities time preparation since the policy makers are leaded to design the activities in line with predetermined priority programs.

The concept of performance-based budgeting is expected to cover the shortcomings appearing in traditional approach because the performance benchmarks for goal achievement and public services objectives are not set (Yuhertiana \& Fatun, 2020b). The weaknesses state above are in line with the World Bank opinion that the resource allocation weakness is due to a weak planning because there is no link among policy makers, the planning, and the budgeting along with inadequate reporting on financial performance.
According to Robinson \& Brumby (2005) budget allocation efficiency will increase if the implementation of medium-term expenditure framework increases; and the implementation of performance-based budgeting at the planning and the budgeting stages increases.

Budget allocation by using function approach (money follow function) as one of the performance-based budgeting principles is a strategic approach in maintaining the effectiveness and efficiency in budget utilization focusing on units whose have relevant task to national performance targets achievement. On several occasions, the President expressed that budget must use money follow program concept. So, how is the actual implementation of this concept in Indonesia budgeting?

\section{Literature Review Budget}

Basically, budget is a plan arranged in quantitative form and monetary units for a time period. The budget period is annual. From budget, people can see the management designs, the priorities, targets and the ways to meet these targets. Budgeting is an activity which has important meaning and role in the cycle of planning and controlling.

Budget as a management tool plays an important role because the management can plans, organizes and evaluates the activities based on it. Novick (1967) argues that budget is a periodic financial plan prepared based on predetermined programs. Budgeting is a budget preparation process containing a statement in the form of money unit which is the activities and performance targets reflection achieved during a certain time period. Budgeting is basically the amount determination process of economic resources allocation for each program and activity in the form of money units.

In this context, the budgeting process is defined as the process which government spending is determined or allocated. The budgeting process usually consists of four main stages: formulation, adoption, execution, and control. These stages interpret the budgeting process broadly. Therefore, the researchers include the planning and the programming which usually precede the four stages and these are not part of the government core fiscal process. Although planning and programming stage are not related to actual cash flows, the budget preparation stage can be part of the corruption process which only manifests itself in actual payments or money transfers during the implementation stage. In fact, one important argument made here is that if the initial stages are executed poorly, this will have an impact later in the process increasing corruption opportunities (Isaksen, 2005; Martí, 2013) .

\section{Performance}

Performance is the achievement level description of the activity /program/organizational policy 
implementation in realizing the strategic goals set by the organization, customer satisfaction, and its contribution to society economic development (Bernardin, Kane, Ross, Spina, \& Johnson, 1995). It can be the work behavior, appearance, or work result. Therefore, performance is a multidimensional building form so the measurement of it varies depending on many factors. Taylor (2016) argues that performance can be judged by the assessment size based on the following indicators: 1) input, 2) output, 3) outcomes, 4) benefit and 5) Impact (Hagedoorn \& Cloodt, 2003). Performance benchmarks are the success achievement measures in each regional work unit. The measure unit is a measure used to see the extent of the work unit carrying out its main tasks and functions. Performance benchmarks are set in the form of service standards determined by each region.

\section{Performance Based Budget (PBB)}

From the various literatures related to the definition of performance-based budgeting, there is a universal definition of performance-based budgeting which is the budget needed to finance expected activities ( the outputs and outcomes are set out in performance targets) so each fund spent can be measured efficiently and effectively. PBB is a budgeting method for management to link any costs involved in activities with the benefits produced (Alkaraan, 2018; Robinson \& Last, 2009) .

A performance-based budgeting is an implemented budget and accounted based on predetermined performance targets achievement expected as a solution of the problems faced in the area (Cinquini, Mauro, \& Pianezzi, 2017). Performance-based budgeting itself is a budgeting connecting each funding included in the expenditure (output) with the results achieved ( outcome) such as efficiency, effectiveness, and economy as an instrument to achieve program goals and objectives (Robinson \& Last, 2009) .

In fact, this system arouses due to the society increasing awareness towards the public dissatisfaction of the government performance. It indicates that current government performance is the spotlight for all society levels since the activities organized implementation should give benefits for the society. It is necessary to measure the organizer implementation. The measurement is made to assess the performance generated in a certain period which is compared with the plans made.

According to Kim \& Park (2008), performance based budgeting is a public budgeting method connecting budget allocations with the achieved results. There are three types of performance based budgeting which are presentational budgeting, performance informed budgeting and direct performance budgeting. Presentational budgeting is a public budgeting format requiring performance information in the budgeting process. However, this performance information has not been used as the basis for determining the budget allocation amount. Second, performance informed budgeting is a public budgeting format using performance information in the decision-making process for budget allocations but it does not automatically affect the budget allocations amount. Third, direct performance budgeting is a public budgeting format linking performance information to public budget allocation policies (Kelly \& Wanna, 2000; Publishing, Committee, \& service), 2007).

Performance-based budgeting (PBB) aims to improve the quality of public budgets. Based on it, the researchers argue that the quality of public budgets is achieved when: 1) state expenditures are carried out efficiently and effectively (operational efficiency), 2) public financial accountability increases and 3) transparency is achieved in public budget management. To achieve budget quality, it is necessary to obtain information and performance facts as the tool used in determining budget allocations (OECD 2007).

Performance-based budgeting is a public budgeting method that has been used by many countries as the members of the OECD since the 1990s. According to the OECD report, performance-based budgeting has positive impacts on increasing public budgets efficiency (OECD 2007). Therefore, the Indonesia government has been starting to adopt the method in the context of budget efficiency since 2005. Performance-based budgeting is an approach in the planning and budgeting system for state expenditure showing the funding allocation, the expected allocation performance, and the efficiency in achieving performance.

Performance-based budgeting is a budgeting process drawing the required project costs and the expected achievement results by government spending; activities funded and the output (output); and the various outputs combination in expected program and the positive impact (outcomes). The effective performance-based budgeting has main principle which is the relationship clarity (link ages) between performance measures at lower levels with a higher hierarchy of objectives/goals in terms of organizational and in terms of the positive impact (outcomes). It can be inferred that performance-based budgeting is a tool to achieve a certain expected performance from a budgeting plan.

\section{Money Follow Program Concept}

The money follow program is implemented by securing allocation to its priorities, reallocating the program activities emphasized in previous years, and streamlining non-priority programs/activities. In money follow program concept, the need for a budgeting approach is based on the program / activity weight in accordance with the objectives set by the government. Programs / activities have high weight if they provide great benefits to society. Through this approach, 1) there will be a high priority weight programs allocation scale for great benefits society program, 2) the funded 
programs and activities are more firm and clear to achieve more optimal and orderly targets, and 3 ) encourage efficiency through clear programs and activities coordination.

The money follow program concept emphasizes the need for a budgeting approach based on the program / activity weight in accordance with the objective set by the government and its assessment phase for proposed programs. Great benefits programs to society will get top budget allocation priority followed by lower weight budget allocation programs. Conversely, if the government streamlines the budget efficiency/savings, the lower weight budget allocation programs must be eliminate since not all government functions are funded. If they do not provide greater benefits to society, they are not funded.

The planning and budgeting process has become a global issue in government discussed not only in Indonesia but also in all countries. The dichotomy between the money follow function and the money follow program issue raises different perceptions even though they have no difference in principle. Both of them prioritize the selection in funding priority programs/activities; emphasize the budget allocations efficiency; and show their transparency and accountability in their performance targets clarity.

\section{Concept of Corruption}

The disclosure of various corruption modes from budget planning to the APBN or APBD implementation process is actually due to performance-based budgeting $(P B B)$ utilization. In essence, $\mathrm{PBB}$ is a budgeting principle oriented towards the results (output) and benefits (outcome) of each rupiah of state / regional money used to finance various central / regional government programs / activities.

The PBB system is a system currently used by developed countries as a substitute of old model budgeting system known as the line item budgeting system. It is a traditional budget model oriented towards input or the budget amount used to finance programs / activities.

Carter (1994) states that PBB uses mission statements, goals, and objectives to explain spending money reason. These missions and objectives setting are allocating resources way to achieve certain goals based on program / activity objectives and measurable results. This concept is regulated in article 7 and article 12 of Law Number 17 of 2003 concerning about the state finance that the preparation of the APBN must refer to the government administration needs (money follow function). Based on this perception, the State Finance Law stipulates that the budget policies formulation to the budget management accountability report can be included in the state finance meaning scope. This implies that the APBN I APBD formulations at legislative proposed by the government have juridical consequences. It means that the budget discussion process is carried out with the legislative council by the budget body included in the state financial management activities accountable phase.

The circulation of legislative members names accused of being associated with the APBN allocation funds to finance the electronic KTP program cannot be separated from the State Finance Law role placing a comprehensive budget accountability system from budget planning in the legislative domain until the budget accountability report is submitted by the executive to legislative. Thus, the use of PBB is a key factor in tracking the various corruption modes occurrence or budget allocation errors.

Political elites and bureaucrats as well as other state administrators should realize that in PBB concept, there are no areas in the state financial management system beyond the internal and external supervision scope. The corruption case of UPS (uninterruptible power supply) procurement fund usage in DKI Jakarta Province was started from DKI Jakarta Regional Budget allocation (APBD) discussion traced by investigators. Moreover, the state finance definition used by Article 1 point 1 of the State Finance Law using a broad and comprehensive approach has placed the state finance scopes from their sources contained in the state or regional budget planning and the state finance flows to various subjects, objects, and programs / activities using state finance funds.

In other words, the authorization function implementation as the basis for income and expenditure implementation political affirmation in political authority realm to allocation and distribution function implementation in program / activity realm duty technocraticly can not be separated from internal and external supervision reach. Various quantitative and qualitative indicators used to measure budget absorption are currently used as a common thread to trace back the budget utilization traces or financial statements and cash flows notes.

PBB can close the gap against administrative malpractices in state/regional finance management. This should be an early warning system for anyone who is responsible for managing state finances starting from policy makers to budget policy implementer that budget corruption will sooner or later be uncovered. There is no longer a gray area for budget corruption and goal oriented.

\section{RESEARCH METHODOLOGY}

This study used a qualitative descriptive analysis approach by collecting data from official documents publication. The purpose of this qualitative research was to describe the research object actual situation. 
Dadang Suwanda, Reydonnyzar Moenek, Sampara Lukman dan Muhammad Syaifullah, The Implementation of Performance-Based Budgeting Through A Money Follow Program in Impressing Budget Corruption

\section{RESULT AND DISCUSSION}

Money follow program as an order or direction from the leader is a clear program. However, as a concept, it is necessary to know the problem faced in money follow function concept understood by budget planning bureaucrats. Many questions arise in this new concept, whether these two concepts are contradict or they have different viewpoint only or perhaps the arising problems are only in optimizing the role and coordination among units involved in planning and budgeting.

In addition to the concepts use, there are other problems in implementing performance-based budgeting in Indonesia. First, the various parties efforts sorting budgets according to sectors indicate that budget planning is no longer needed because budget allocations are divided based on the sectoral law mandate. This implies that clear performance formulations or strong linkages between programs /activities and their outputs are no longer needed. All of them are not necessary since each sector which the budget guarantee stated in the legislation does not need sophisticated planning.

Second, the 'let the managers manage' aspects implementation as performance-based budgeting application next step needs to be more elaborated and optimal. Its concept gives creativity freedom for the ministries/agencies leadership for successful performance targets. Besides, the budgeting realm central government such as budget directorate general must see the "let the managers manage' implementation as a transitional work tasks from administrative task or the budget document arrangement and establishment to strategic task-work such as the review baseline or linking additional budget with development priority issues in the trilateral meeting forum .

The planning and budgeting process are the important processes because the process results indicate the organization movement. Therefore the planning and budgeting process are continuously improved to achieve credible budget. One of the efforts to improve it is by introducing the money follow program principle. It was launched by President Jokowi at the 2017 Government Work Plan kick-off preparation as a substitute for money follow function principle. Starting from the lack of the ministries / agencies budget allocation focus analysis especially in supporting government priorities, the president directed that the budget must be allocated to the government's priority or main agenda activities. It is common in the planning and budgeting process that ministries / agencies tend to allocate budgets evenly (peanut butter costing) rather than to allocate budget based on priorities activities/programs so many of the activities/programs received minimum budget. Budget allocation is usually carried out based on tasks and functions only rather than priorities activities to achieve national development goals and to provide the best benefits to society.

\section{Why Should Money Follow Program?}

Budget priority has been a crucial thing since government faces challenges in its envelope resources that should meet all development program needs. Tax revenue as the support main source for the state budget is still limited in its ability to meet the development agenda funding needs. The unrecovered world economy has contributed to the less optimal achievement of state coffers from the taxation sector so the government resources to finance development are limited. This limited expenditure resource is inversely to society high demands towards the government services. Accelerating government spending on infrastructure and the increasing need for mandatory spending also requires a large budget. Basic infrastructure provision; energy needs fulfillment; adequate transportation facilities; and better public service such health and education sectors are several development focuses voiced continuously by various groups. Therefore, the government mandates the ministries/agencies to focus their budgets in supporting the government performance achievement especially on high national leverage programs. These programs are externally oriented for providing benefits to the government bureaucracy. This is in line with the 2018 Government Work Plan preparation theme based on Presidential Decree number 79 of 2017 concerning about the 2018 Government Work Plan entitle "spurring investment and infrastructure for growth and equity". This means that ministry / agency budget allocations should be focused on supporting this achievement theme.

\section{Operationalization of the Money Follow Program}

The next question is how to make the money follow program approach concrete in the planning and budgeting process. The Finance Ministry as a K / L applies this approach by strengthening the resource forum as communication tool for agreeing on performance targets and budgeting support needed between the resource function manager and the technical function manager. This forum is in line with money follow program principle considering proposed work plans and strategic initiatives for the coming year by taking into account the previous year achievements and current year projections. It is also carried out in stages both at the ministerial level and at the echelon I level so ownership and commitment will be created from priority activities owners. It is designed during the work plan preparation or indicative part, work plan preparation, and ministry / agency budget or budget usage determination time and budget allocation determination time.

To facilitate discussion at the work plan formulation stage, each of this priority activity proposal or strategic initiative is outlined in a document called the Comprehensive Budget Document (CBD). It provides information comprehensive overview starting from the profile, performance measurement, risk profile, person in 
Dadang Suwanda, Reydonnyzar Moenek, Sampara Lukman dan Muhammad Syaifullah, The Implementation of Performance-Based Budgeting Through A Money Follow Program in Impressing Budget Corruption

charge, implementation timeline, achievement trajectory, and activity budget requirement. These documents are used as the various forums references discussing work plans and various party budgets. These provide the prior information on the priority activity or strategic initiative presented before the budget allocation approval.

The priority activities are mandatory (top down) from the central government. The allocation is determined through a series of meetings coordinated by Bappenas such as discussions on multilateral meetings with ministries/institutions as the leading sector including discussions at the national development deliberation forum aligned with the regional government budget agenda. There are several national priorities supported by the Finance Ministry in 2018 such as national health priority; business development and tourism; energy security; poverty alleviation; regional development; and law politic and security defense.

One example of the regional development national priorities is a rural development priority program by strengthening village governance priority activities. The finance ministry contributes through village fund training implementation to increase village fund manager capacity. It is important due to the increasing village budget allocations from year to year. Through increasing the manager capacity, village fund multiplier effect in development will be more optimal.

Besides top-down, priority activity or strategic initiative proposal can come from the ministry ( bottom up ) through discussion forum among the ministerial and all program plan owners or echelon I officials for agreeing on the priority activity plan or strategic initiative. The agreement is from the bureaucratic reform initiative and institutional transformation especially the outcome orientation and the national impact. In line with the Finance Ministry duties and functions, several initiative agreements focus on the central theme, the income theme, the budgeting theme and the treasury theme. On the central theme as the example, Finance Ministry gives culture strengthening especially the efficiency culture.

From the revenue aspect, there are initiatives to increase tax revenues and non-tax state revenues through the information system modernization. Likewise, budgeting and treasury are demanded to be more efficient in allocating and in its implementation through simplifying the administrative process while maintaining accountability. Alternative proposed priority activities can also refer to the medium-term or strategic planning document which is better known as the government's strategic plan.

The Renstra document becomes one of the references which the document has achieved targets along with strategic objectives including success measures. In operational manner, it also describes the policy direction and achievement strategy. This strategy is manifested in the real priority activities form for the ministry.

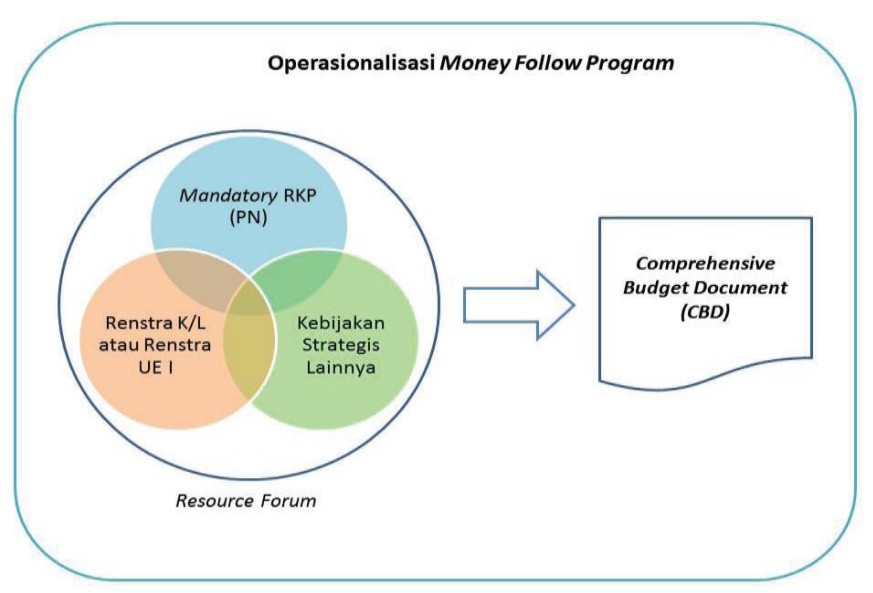

\section{Implementation Challenges and Way Forward}

This change brings challenges in the existing process. The habitual budget allocation focusing on routine activities allocations rather than strategic matters or breakthroughs cannot be changed in a short time. In practice, strategic matter should have budget allocation to avoid additional budget demand.

In addition, even though the activities/programs are strategic and funded, the allocation amount determination should consider efficiency principle. The Finance Ministry directs these strategic activities to meet their allocations from the less strategic budget allocations refocusing or core function units implementation as an alternative effort to meet budgetary needs. If it cannot be done in an echelon I unit by reallocating budgets between activities, reallocation can be made between programs or between echelon I units. In usual input, it can be done by streamlining expenditures for goods related to official travel, team honorarium or other unproductive spending.

No less important, after carrying out budget prioritization, the monitoring and evaluation implementation are done to ensure the implementation running in line with the plan. To build harmony in performance managements, these priorities can be used as strategic initiatives and their performances can be continuously monitored by considering their risk map so the potential disrupting things or less optimal performances can be mapped and mitigated in the beginning. In other words, the money follow program can be a catalyst for the performance-based budgeting implementation; and harmonizes the planning, the budgeting and the performance management.

\section{CONCLUSION}

Budget prioritization in government is definitely a crucial thing done as the consideration of limited government envelope resources for meeting all development program needs. Tax revenue as the main source to support APBN has limited ability to meet the development agenda funding needs. The unrecovered world economy has contributed to less optimal 
achievement of state coffers from the taxation sector so the government resources to finance country development are limited. This expenditure resource limitation is inversely to the high society demands towards the government high performance. Accelerating government spending on infrastructure and the increasing need for mandatory spending requires a large budget. Basic infrastructure provision, meeting energy need, and adequate transportation facility are several development focuses voiced continuously by various groups such as the demand for better public services in the health and education sectors. Therefore, it is not an exaggeration if the government mandates ministries / agencies to focus their budgets to support government performance achievements especially on high national leverage programs. These programs are not only giving benefits to the government bureaucracy but also more externally oriented which means that budget allocations for ministries / agencies should be focused on supporting this theme achievement.

\section{Acknowledgments.}

The authors would like to thank the Ministry of Finance; the Ministry of Home Affairs; the Supreme Audit Agency; and the Finance and Development Audit Agency for facilitating this research as well as to Government officials at the Ministry of Finance and the Ministry of Home Affairs who have deigned to participate in giving the data as an expert informant in this study.

\section{REFERENCES}

Alkaraan, F. (2018). Public financial management reform: an ongoing journey towards good governance. Journal of Financial Reporting and Accounting, $\quad$ 16(4), 585-609. https://doi.org/10.1108/JFRA-08-2017-0075

Andrews, M. (2006). Beyond 'best practice' and 'basics first'in adopting performance budgeting reform. Public Administration and Development: The International Journal of Management Research and Practice, 26(2), 147-161.

Andrews, M., \& Hill, H. (2003a). The impact of traditional budgeting systems on the effectiveness of performance-based budgeting: A different viewpoint on recent findings. International Journal of Public Administration, 26(2), 135-155. https://doi.org/10.1081/PAD-120018299

Andrews, M., \& Hill, H. (2003b). The impact of traditional budgeting systems on the effectiveness of performance-based budgeting: A different viewpoint on recent findings. International Journal of Public Administration, 26(2), 135-155. https://doi.org/10.1081/PAD-120018299

Ateh, M. Y., Prasojo, E., \& Huseini, M. (2019, December 4). The Impact of Performance Management
Implementation on Effectiveness and Efficiency of Government Budget Use: Indonesian case. 55-64. https://doi.org/10.2991/eropa-18.2019.7

Bernardin, H. J., Kane, J. S., Ross, S., Spina, J. D., \& Johnson, D. L. (1995). Performance appraisal design, development, and implementation. Handbook of Human Resource Management, 462, 493.

Cinquini, L., Mauro, S. G., \& Pianezzi, D. (2017). The illusion of New Public Management? An analysis of performance-based budgeting in the public sector. Proceedings of Pragmatic Constructivism, 6(1), 14-25. Retrieved from https://www.propracon.com/article/view/25144

De Vries, M. S., \& Nemec, J. (2019). Dilemmas in Performance-Based Budgeting. https://doi.org/10.1007/978-3-030-02077-4_1

Ellul, L., \& Hodges, R. (2019). Reforming the government budgeting system in Malta: Pressures promoting or hindering the reform. Journal of Public Budgeting, Accounting and Financial Management, 31(4), 518-538. https://doi.org/10.1108/JPBAFM-10-2018-0108

Hagedoorn, J., \& Cloodt, M. (2003). Measuring innovative performance: Is there an advantage in using multiple indicators? Research Policy, 32(8), $1365-1379$.

https://doi.org/10.1016/S0048-7333(02)00137-3

Hijal-Moghrabi, I. (2019). Why Is it So Hard to Rationalize the Budgetary Process? A Behavioral Analysis of Performance-Based Budgeting. Public Organization Review, 19(3), 387-406. https://doi.org/10.1007/s11115-018-0410-1

Isaksen, J. (2005). The budget process and corruption. U4 Issue Paper, (3), 1-25. Retrieved from http://scholar.google.com/scholar?hl=en\&btnG=S earch\&q=intitle:The+budget+process+and+corrup tion\#1

Kelly, J., \& Wanna, J. (2000). New Public Management and the politics of government budgeting. International Public Management Review, 1(1), 33-55.

Kim, J. M., \& Park, N. (2008). Performance Budgeting in Korea. OECD Journal on Budgeting, 7(4), 1-11. https://doi.org/10.1787/budget-v7-art21-en

Kıral, H., \& Akdemir, T. (Eds.). (2020). Public Financial Management Reforms in Turkey: Progress and Challenges, Volume 1. https://doi.org/10.1007/978-981-15-1914-7

Laurenceson, J., \& Chai, J. C. H. (2003). Financial reform and economic development in China. Edward Elgar Publishing.

Martí, C. (2013). Performance budgeting and accrual budgeting. Public Performance and Management Review, 37(1), 33-58. https://doi.org/10.2753/PMR1530-9576370102 
Dadang Suwanda, Reydonnyzar Moenek, Sampara Lukman dan Muhammad Syaifullah, The Implementation of Performance-Based Budgeting Through A Money Follow Program in Impressing Budget Corruption

Mazur, S. (2020). Public Administration in Central Europe: Ideas as Causes of Reforms. Routledge.

Miller, G. (2018). Performance based budgeting. Routledge.

Novick, D. (1967). Program budgeting: program analysis and the federal budget. Harvard University Press.

Publishing, P. O., Committee, D. D. A., \& service), S. (Online. (2007). The OECD DAC Handbook on Security System Reform: Supporting Security and Justice. oecd.

Robinson, M. (2013). Performance Budgeting. In The International Handbook of Public Financial Management (pp. 237-258). https://doi.org/10.1057/9781137315304_12

Robinson, M., \& Brumby, J. (2005). Does performance budgeting work? An analytical review of the empirical literature. International Monetary Fund.

Robinson, M., \& Last, M. D. (2009). A basic model of performance-based budgeting. International Monetary Fund.

Siti-Nabiha, A. K., \& Jurnali, T. (2020). Institutional work and implementation of a performance measurement and management system in a developing country. Journal of Accounting and Organizational Change. https://doi.org/10.1108/JAOC-07-2018-0060

Taylor, Z. (2016). Good Governance at the Local Level : Meaning and Measurement. Institute on Municipal Finance and Governance.

Wang, X. (2000). Performance measurement in budgeting: A study of county governments. Public Budgeting and Finance, 20(3), 102-118. https://doi.org/10.1111/0275-1100.00022

Yenice, E. (2020). Program Budgeting in Turkey. https://doi.org/10.1007/978-981-15-1914-7_8

Yuhertiana, I., \& Fatun, F. (2020a). Performance-based budgeting in public sector and managerial performance with leadership as moderating variable. International Journal of Service Management and Sustainability, 5(1), 177-204.

Yuhertiana, I., \& Fatun, F. (2020b). Performance-Based Budgeting in Public Sector and Managerial Performance with Leadership as Moderating Variable. International Journal of Service Management and Sustainability, 5(1), 177. https://doi.org/10.24191/ijsms.v5i1.9865

Zhang, X., Tantardini, M., Kim, Y., \& de Lancer Julnes, P. (2020). Is Performance Management Reform Living up to its Expectations? An Analysis of Public Management Reform in China's Guangdong Province. Public Performance and Management Review. https://doi.org/10.1080/15309576.2020.1806085 